\title{
Rice Husk Biochar for Rice Based Cropping System in Acid Soil 1. The Characteristics of Rice Husk Biochar and Its Influence on the Properties of Acid Sulfate Soils and Rice Growth in West Kalimantan, Indonesia
}

\author{
Agusalim Masulili \\ Pancabhakti University \\ Jl. Kom Yos Sudarso, Pontianak, West Kalimanatan, Indonesia \\ Wani Hadi Utomo (Corresponding author) \\ Center for Soils and Land Resources Management, Brawijaya University \\ Jl. Veteran, Malang 65144, East Java, Indonesia \\ Tel: 62-341-553-623 E-mail: hadi_utomo@hotmail.com \\ Syechfani MS \\ Center for Soils and Land Resources Management, Brawijaya University \\ Jl. Veteran, Malang 65144, East Java, Indonesia
}

This works was sponsored by Indonesian Department of National Education, under PhD research and PAR scheme.

\begin{abstract}
The experiments were carried out to study the characteristics of biochar made from rice husk and its potential as a soil amendment in acid soils. Biochar was produced by pyrolysis; after which it was applied as a soil amendment. The soil was incubated for 30 days, and then it was planted with rice. For comparison, soil was applied with: rice straw, rice husk, rice husk ash, Chromolaena odorata biomass, and no soil amendment. The characteristics of biochar were: water content $4.96 \%$, pH 8.70 , C $18.72 \%$, P $0.12 \%$, CEC $17.57 \mathrm{cmol} \mathrm{kg}^{-1}, \mathrm{~K} 0.20 \%$, Ca $0.41 \%$, Mg $0.62 \%$, and $\mathrm{Na} 1.40 \%$. Application of biochar decreased soil bulk density, soil strength, exchangeable $\mathrm{Al}$, and soluble $\mathrm{Fe}$ and increased porosity, available soil water content, $\mathrm{C}$-organic, soil $\mathrm{pH}$, available $\mathrm{P}, \mathrm{CEC}$, exchangeable $\mathrm{K}$, and $\mathrm{Ca}$. Out of these improvements, only soil carbon, phosphorus, exchangeable $\mathrm{Al}$, soluble $\mathrm{Fe}$, and soil strength significantly influenced rice biomass.
\end{abstract}

Keywords: Biochar, Soil amendment, Rice straw, Soil strength, CEC

\section{Introduction}

Increasing food production both to meet in-country requirements and to help the world overcome food crises is one of the major issues facing Indonesia today. However, good productive land is limited and has mostly been utilized either for food crop production or other uses. The only available land for agricultural expansion is that of acid sulfate soil, having a total area of about 6.7 millions ha and is spread out in Sumatera, Kalimantan, and Papua (Widjaja-Adi et al., 1992). These soils have a high iron sulfate mineral content of predominantly Pyrite, and when the soil is drained it will release sulfuric acid, which in turn will release $\mathrm{Fe}, \mathrm{Al}$, and other heavy metals that are dangerous for plants and other living organisms. When these soils are used for rice, Moore (1990) found that the most important constraints were: (i) acidity (which includes the combined effects of $\mathrm{pH}, \mathrm{Al}$ toxicity, and $\mathrm{P}$ deficiency), and (ii) Fe stress (which is due to the combined effects of Fe toxicity and deficiencies of other divalent cations such as $\mathrm{Ca}$ ).

The acid sulfate soil in Sungai Kakap, West Kalimantan has been utilized for intensive rice growing since 1980. Thus, in addition to the above problems, growing rice in these lands faces the problem of soil compaction due to intensive tillage with puddling and removal of biomass continuously. Measurement prior to the conduction of the experiment showed that soil organic matter in these soils was less than $0.9 \%$. In this soil, organic matter is very important because in addition to being a source of plant nutrition, organic matter is the major source of negative charge, which is important for helping the soil to adsorb cations in the soil solution (Ponamperuma, 1982) 
A common treatment to reduce the solubility of $\mathrm{Al}, \mathrm{Fe}$ and other heavy metals in soil is to increase the soil $\mathrm{pH}$, which is mostly done by liming (Ahmad and Tan, 1982; Hakim et al., 1989; Haby, 2002). The ability of liming to increase soil $\mathrm{pH}$, decrease $\mathrm{Al}$ and Fe solubility, and increase crop yield is widely known (Shamshuddin and Auxtero, 1991; Haby, 2002; Kadery, Brown et al., 2008). In Indonesia, the source of lime materials exists mostly in Java, which is far from the location where the liming needs to be done. Furthermore, liming only treats the symptoms of acid sulfate soils rather than the cause (Thomas et al., 2003); therefore, the beneficial effects of liming are short lived, and it has to be done repeatedly (Shamsuddin et al., 1998). This makes liming very expensive and it is often un-economic for small farmers to obtain lime materials.

The other treatment suggested for improving the properties of acid sulfate soil is the application of organic matter (Kaderi, 2004; Shamsuddin et al., 2004). With negative charge provided by carboxyl compounds, organic matter is able to minimize toxicity by decreasing the solubility of heavy metals in the soil solutions. Positive effects of organic matter application on the properties of acidic soils, such as increasing soil $\mathrm{pH}$ and $\mathrm{CEC}$, and decreasing heavy metal toxicity, have been reported elsewhere (see Hesse, 1982; El Sharkawi et al., 2006). Organic matter is easy to find locally and is relatively cheap, especially if the organic matter used is the un-harvested biomass of the crop itself.

For rice-based cropping systems, the use of rice straw and rice husk has been practiced for a long time (Ponamperuma, 1982; Eagle et al., 2000; Singh et al., 2008; Kaewpradit et al., 2009). The advantages and drawbacks of burning vs incorporation of rice straw in rice growing have been discussed by Williams et al. (1972). Sitio et al. (2007) used rice husk ash (RHA) for the improvement of rice growth and yield in the peat soil of Sumatra. Karmakar et al. (2009) studied the effect of application of fly ash, rice husk ash, and paper factory sludge on the growth and yield of rice in the acid lateritic soil of India. They showed that the application of these industrial wastes improved soil properties by decreasing soil bulk density and increasing soil $\mathrm{pH}$, organic carbon, available nutrients, and rice yield. The ability of rice husk and rice husk ash to remove heavy metals from the system has also been shown by Mahvi et al. (2005). Again, the main limitation in using such organic matter is the easiness of these materials to be decomposed, and therefore its application must be done repeatedly from year to year. On the other hand, there is now competition in biomass utilizations with the emergence of demand in the sectors of energy resources and animal feeding. In addition, decomposition and mineralization of organic matter has been attributed as one of the major sources of global warming due to emissions of methane and nitrous-oxide (Rondon et al., 2007)

Lately, looking the recalcitrant of C-organic in a black carbon material which is also known as biochar, many scientists interested in using this black carbon material as a soil amendment (Glasser et al., 2002; Topolianz et al., 2007; Woolf, 2008). Although there are still some objections (Ernsting and Smolker, 2009; Senjen,2009), a lot of experimental results have indicated that biochar applications can improve soil properties (Lehman et al., 2003; Liang et al., 2006; Chan et al., 2007) and increase crop yield (Yamato et al., 2006; Chan et al., 2008 ). Chan et al. (2007) showed that biochar application had improved some physical soil properties, such as increased soil aggregation, water holding capacity, and decreased soil strength. An increase in saturated hydraulic conductivity of upland rice soil with biochar application has been reported by Asai et al. (2009). Furthermore, Chan et al. (2007) also showed that the application of biochar could increase soil organic carbon, soil $\mathrm{pH}$, and CEC. The increase of CEC with the application of biochar has also been shown by Liang et al. (2006). Yamato et al. (2006) showed that the application of biochar made from Acacia magnum could increase soil pH, Ca, base saturation, and CEC and decrease $\mathrm{Al}^{+}$saturation. Novak et al. (2009) showed that the application of biochar in the acidic coastal soil of the Southern US could increase soil $\mathrm{pH}$, soil organic matter, Mn, and $\mathrm{Ca}$ and decrease $\mathrm{S}$ and $\mathrm{Zn}$. On this sandy soil, the application of biochar did not significantly influence the CEC of the soil. The increase in soil biological activity has been reported by Rondon et al. (2007) for nitrogen fixation in Phaseolus vulgaris L. and by Chan et al. (2008) for earthworm and microbial biomass.

The increase in crop yield with biochar application has been reported elsewhere for crops such as cowpea (Yamato et al., 2006), soybean (Tagoe et al., 2008), maize (Yamato et al., 2006; Rodríguez et al., 2009), and upland rice (Asai et al., 2009). Haefele (2007) and Haefele et al. (2008) discussed the possibility of biochar applications for rice-based cropping systems. Reichenauer et al. (2009) applied biochar in tsunami-affected paddy fields in Sri Lanka, and the experimental results showed that the application of $2 \mathrm{t}$ rice-husk-charcoal ha ${ }^{-1}$ increased the grain yield from less than $4 \mathrm{t}$ ha ${ }^{-1}$ for the control treatment to more than $5 \mathrm{t} \mathrm{ha}^{-1}$ for the biochar treatment.

The objective of the works reported here was to study the characteristics of biochar produced from rice husk grown in acidic soil and its potential to improve the properties and productivity of acid sulfate soils and the growth of lowland rice in West Kalimantan, Indonesia.

\section{Materials and methods}

\subsection{Production and characterization of biochar}

To ensure that the rice husk had come from the acid sulfate soil of West Kalimantan, Indonesia, we harvested it directly the rice from the field and then brought it for rice milling to get the rice husk. The rice husk was then put in a piece of pyrolysis apparatus which consisted of a stainless reactor of $500 \mathrm{~mm}$ length with a $15 \mathrm{~cm}$ inside diameter. The rice husk 
was then heated externally by an electric furnace $(5000 \mathrm{~W})$ to a temperature of $600{ }^{\circ} \mathrm{C}$. The reactor for the biochar production is presented in Figure 1.

The Biochar was ground to pass through a $0.50 \mathrm{~mm}$ sieve. The Biochar moisture content was measured by oven drying a sub sample of $2 \mathrm{~g}$ at a temperature of $80^{\circ} \mathrm{C}$ for 24 hours. Biochar characterization was done according to the method described by Ahmedna et al. (1997). The bulk density was determined by filling a $10 \mathrm{ml}$ tube with dry ground biochar. The tubes were capped, tamped to a constant volume, and weighed. Bulk density was calculated by dividing the weight of the dry sample with the volume of the packed materials.

To measure the $\mathrm{pH}, 1 \%$ suspensions of biochar were prepared by diluting the biochar with de-ionized water. Then they were heated to about $90{ }^{\circ} \mathrm{C}$ and stirred for 20 minutes to allow the dissolution of the soluble biochar components. The suspensions were then cooled to room temperature, after which the $\mathrm{pH}$ was measured with a $\mathrm{pH}$-meter (Jenway 3305). Total C determination was done using the method described in ASTM D 3176 (ASTM, 2006). Total P was read with a spectrometer (Vitatron) and $\mathrm{Ca}, \mathrm{Mg}, \mathrm{Na}$, and $\mathrm{Si}$ were measured using AAS (Shimatzu)

\subsection{Experimental setup}

A glass house experiment was set up to study the effect of rice husk biochar on rice growth. The soil used was collected from the experimental station of BPTP West Kalimantan in Sungai Kakap. Soil samples were collected from depths of up to $20 \mathrm{~cm}$, and then dried, ground, and passed through a $2.0 \mathrm{~mm}$ sieve. $5 \mathrm{~kg}$ of ground soil was then put in a plastic pot with an inside diameter of $30 \mathrm{~cm}$. The organic soil amendments used were:

(1) No soil amendment, as the control (Co)

(2) Rice Straw (RS), $15 \mathrm{t} \mathrm{ha}^{-1}$

(3) Rice husk (RH), $15 \mathrm{tha}^{-1}$

(4) Rice husk ash (RHA), $10 \mathrm{tha}^{-1}$

(5) Rice husk biochar (RHB), $10 \mathrm{tha}^{-1}$

(6) Chromolaena odorata (Chr), $15 \mathrm{t} \mathrm{ha}^{-1}$

These six treatments were arranged in Fully Randomized Design with 4 replications. The amount of soil amendment applied was calculated based on the surface area of the plastic pot, and the amendments were mixed to a $20 \mathrm{~cm}$ depth, after which they were incubated at water content close to the field capacity for 30 days.

Rice straw, rice husk, and Chromolaena odorata were chopped and ground, and rice husk ash and rice husk biochar were ground and passed through a sieve with a $2.0 \mathrm{~mm}$ diameter. Chromolaena odorata is a bush plant which grows extensively in West Kalimantan. At the end of incubation, soil strength was measured with a hand penetrometer (Daikie) to a depth of $15 \mathrm{~cm}$, then 2 undisturbed samples of about $50 \mathrm{~g}$ were taken for bulk density and soil water determination; and a disturbed sample of about $100 \mathrm{~g}$ was taken for chemical properties analysis.

Twenty day old rice seedlings were transplanted to this incubated soil. The rice plants were grown as lowland rice, and they were fertilized with $135 \mathrm{~kg} \mathrm{~N} \mathrm{ha}^{-1}, 72 \mathrm{~kg} \mathrm{P}_{2} \mathrm{O}_{5} \mathrm{ha}^{-1}$ and $50 \mathrm{~kg} \mathrm{~K}_{2} \mathrm{O} \mathrm{ha}^{-1}$. The plants were harvested at 45 days after planting, and measurements were done for plant height, number of tillers, productive tillers, and total dry mass.

\subsection{Soil Analysis}

Particle size analysis was performed by the pipette method (Soil Survey Laboratory Staff, 1992), and soil bulk density was determined by the clod method as described by Blake and Harke (1986)

Total porosity was calculated from the soil water content $(\mathrm{v} / \mathrm{v})$ at a matrix potential of $0 \mathrm{kPa}$, and available soil water was calculated by subtracting the soil water content at a matrix potential of $-33 \mathrm{kPa}$ (field capacity) with that at a matrix potential of $-15 \mathrm{MPa}$ (wilting point). The soil water content at these matrix potentials was determined using pressure plate apparatus.

Soil $\mathrm{pH}$ was measured in 1:2.5 ratio soil solutions (with de-ionized water) with a pH meter (Jenway 3305). The Walkley and Black wet oxidation method was used to determine organic C content (Soil Survey Laboratory Staff, 1992). Total N content was measured by the Kjeldhal method (Bremner and Mulyaeny, 1982). Exchange $\mathrm{Al}^{3+}$ and $\mathrm{Fe}^{2+}$ were extracted with $1 \mathrm{M} \mathrm{KCl}$ (Barnhisel and Bertsch, 1982). The CEC was extracted with $1 \mathrm{M} \mathrm{NH}_{4} \mathrm{Oac}$ (buffered at pH 7.0), and exchangeable base concentrations were measured using AAS (Shimatzu).

\section{Results and discussion}

\subsection{Characteristics of the biochar}

The analytical results presented in Table 1 show that biochar made from rice husk grown in acidic soil had slightly alkaline properties with a $\mathrm{pH}$ of 8.7, relatively higher than that of rice husk ash. Compared to rice straw and rice husk, rice husk ash and rice husk biochar had a higher elemental $\mathrm{Ca}, \mathrm{Mg}$, and $\mathrm{Na}$, but a lower content of C-organic. Thus 
burning rice husk, either by pyrolysis which produces biochar, or directly fire burned rice husk which produces rice husk ash, decreases organic carbon in the materials. Rice husk biochar had a CEC of $17.57 \mathrm{cmol} \mathrm{kg}^{-1}$, and this was much higher than that of rice husk ash.

A comparison of rice straw and rice husk shows that, except in C-organic content, both materials have relatively similar properties. The C-organic content of rice husk was relatively higher than that of rice straw. Except in C-organic content, which is lower than in that of rice straw, the properties of soil amendment made from Chromolaena is about the same as those of amendments made from rice straw and rice husk.

\subsection{Soil properties}

Applications of organic soil amendments improve some of the physical properties of acid sulfate soil of West Kalimantan (Table 2). Bulk Density (BD) decreased from $1.24 \mathrm{Mg} \mathrm{m}^{-3}$ in the control experiment to $1.14 \mathrm{Mg} \mathrm{m}^{-3}$ in the rice straw treated soil. The BD of the soil treated with rice husk biochar was $1.17 \mathrm{Mg} \mathrm{m}^{-3}$, which is not significantly different to that of soil treated with the rice straw soil amendment. The decrease of soil bulk density with the organic soil amendment application in this treatment could be explained as being a result of the incorporation of the soil which has a relatively high $\mathrm{BD}\left(1.24 \mathrm{Mg} \mathrm{m}^{-3}\right)$ and a lower density of organic soil amendment (less than $1.00 \mathrm{Mg} \mathrm{m}^{-3}$ ). However, looking at the total soil porosity and available soil water (Table 2), it is un-doubtable that the decrease in soil bulk density of the soil treated with organic soil amendment was, at least partly, due to the formation of soil aggregate.

The increase in soil porosity with soil aggregation, which in turn will decrease soil bulk density, has been discussed elsewhere (see for example, Harris et al., 1966). This process will increase total porosity, and at the same time will increase soil water retention (Sharma and Uehara, 1968). Since water retention in micro pores (equal to a matrix potential of $-15 \mathrm{MPa}$ ) is relatively constant, this process will increase the available soil water. The result in Table 2 shows that application of organic soil amendment increases total soil porosity from about $40 \%$ (control) to more than $50 \%$ in all treated soil. The increase in total soil porosity was followed by the increase in available soil water from $11.34 \%$ for untreated control soil to $15.47 \%$ for rice husk biochar treated soil.

As a consequence of the formation of soil pores by aggregation and a decrease in soil bulk density, soil strength, which was measured as the resistance of the soil to penetration, will decrease (Goodman and Ennos, 1999). In untreated control soil with a soil bulk density of $1.24 \mathrm{Mg} \mathrm{m}^{-3}$, the penetration resistance was $500 \mathrm{Nm}^{-2}$ decreasing to $390 \mathrm{Nm}^{-2}$ in rice husk ash treated soil. The penetration resistance of rice husk biochar treated soil was $393.34 \mathrm{Nm}^{-2}$. This is not significantly different from that of rice husk ash treated soil. The decrease of soil strength with application of biochar has also been observed by Chan et al. (2007) for hard settling soil in Australia.

The effect of rice husk biochar and other soil amendments on the chemical properties of acid sulfate soil in West Kalimantan is presented in Table 3. In general, application of organic soil amendments significantly improved the chemical properties of acid sulfate soil. There was an increase in soil organic matter content, soil $\mathrm{pH}$, and $\mathrm{CEC}$ and a decrease in exchangeable $\mathrm{Al}$ and soluble $\mathrm{Fe}$. The results in Table 3 also show that application of organic soil amendments increased the content of $\mathrm{P}, \mathrm{K}$ and $\mathrm{Ca}$, but did not significantly influence the amount of $\mathrm{Mg}$ and $\mathrm{Na}$. The highest CEC, $\mathrm{P}$ and $\mathrm{K}$ were observed in soil treated with rice husk biochar, but did not significantly different from that of treated with rice husk ash.

Rice husk ash and rice husk biochar had a high $\mathrm{pH}$ (Table 1); therefore, it is reasonable that the soil treated with rice husk biochar and rice husk ash also had a high $\mathrm{pH}$. This result indicated that rice husk biochar could be used as a substitution for lime materials to increase the $\mathrm{pH}$ of acidic soils. The increase in CEC of the soil with organic soil amendments would probably be due to the negative charge arising from the carboxyl groups of the organic matter. The increase in CEC and soil $\mathrm{pH}$ with the addition of organic matter has been shown elsewhere (see Bot and Benites, 2005). Biochar has a high CEC (see Table 1), and with its high recalcitrance (Glaser et al., 2002), it is reasonable that soil applied with biochar had the highest CEC. An increase in soil CEC with the application of biochar has also been shown by Chan et al. (2007)

The decrease in exchangeable $\mathrm{Al}$ and soluble $\mathrm{Fe}$ in rice husk biochar and other organic soil amendments is undoubtedly due to the increase of CEC in the soil. The results in Table 3 show that exchangeable Al and soluble Fe decreases as CEC increases. The improvement of the soil's physical properties, especially soil aggregation, might also contribute to the lowering of $\mathrm{Fe}$ in lowland rice. This soil structure improvement will make the soil condition more oxidative so the solubility of the Fe decreases.

The increase in elemental plant nutrients $\mathrm{P}, \mathrm{K}$, and $\mathrm{Ca}$ is as a result of addition of plant nutrients in the organic soil amendments as has been suggested by Ponamperuma (1982). For the P nutrient, however, this increase could have also been as a result of increasing the soil $\mathrm{pH}$ due to rice husk ash or rice husk biochar application. It is interesting to note that, although the C-organic content in rice husk biochar is lower than that of rice straw or rice husk, the highest level of soil organic matter was observed in rice husk biochar tretaed soil. This phenomenon indicated the recalcitrance of 
C-organic in rice husk biochar as has been suggested by many researchers (e.g. Glasser et al. 2002; Lehman et al., 2003; Rondon et al., 2007)

\subsection{Rice growth}

The improvement of the soil's physical and chemical properties due to rice husk biochar and other organic soil amendment applications was followed by the improvement of the growth of rice planted in this acid sulfate soil (Table 4). Plant height, number of tillers, number of productive tillers, and total dry biomass of rice grown in organic amendment treated soils were significantly $(\mathrm{p}=0.05)$ higher compared to that of un-treated soil.

The highest number of tillers was obtained by rice husk biochar treatment. However, from a total dry biomass point of view, soil treated with Chromalaena amendments produced the highest yield with $76.5 \mathrm{~g}$ per plant, although it does not significantly differ to that produced by the rice husk biochar amendment.

There were many factors contributing to the improvement of this rice growth, and these factors can work either individually or simultaneously. Indeed, the decrease in exchangeable Al and soluble Fe would have been important factors for this growth improvement. The contribution of elemental plant nutrients from the organic soil amendments, especially P, would have also had an important effect. As shown by the results given in Table 3, application of organic soil amendments increased the available $\mathrm{P}, \mathrm{K}$, and $\mathrm{Ca}$ in the soil; however, the influence of the soil's physical improvement, especially the increase in soil macro pores and the decrease in soil strength can not be neglected.

From looking at an individual correlation analysis, there was a significant correlation between the rice biomass yield with soil organic matter content $(r=0.836)$, total $\mathrm{P}(\mathrm{r}=0.834)$, exchangeable $\mathrm{Al}(\mathrm{r}=-0.864)$, soluble Fe $(\mathrm{r}=-0.913)$ and soil strength, $\mathrm{Qp}(\mathrm{r}=-0.814)$. Thus rice biomass increased with increasing soil organic matter content and total $\mathrm{P}$, and decreased with decreasing exchangeable Al, soluble Fe, and soil strength. Multiple regression analysis of these factors with rice biomass yielded a regression equation of:

\section{Conclusion}

$$
\text { Rice biomass }=-1660.5-454.31 \mathbf{C}+13001.71 \mathbf{P}-45.20 \mathbf{A l}+218.00 \mathbf{F e}-2.81 \mathbf{Q p}
$$

The experimental results of biochar made from rice husk grown in acid sulfate soil and other organic soil amendment applications significantly improve some properties of the acid sulfate soil of West Kalimantan, Indonesia, namely: decreasing soil bulk density, soil strength, exchangeable Al, and soluble Fe, and increasing soil pH, soil organic matter, total $\mathrm{P}, \mathrm{CEC}$, exchangeable $\mathrm{K}$, and exchangeable $\mathrm{Ca}$.

The improvement of soil properties with organic soil amendment applications resulted in an improvement of rice growth as shown by an increase in plant height, number of tillers, and dry biomass. A significant negative correlation occurred between dry biomass and exchangeable Al, soluble Fe, and soil strength; and a significant positive correlation occurred between dry biomass, soil organic matter, and total P.

\section{Acknowledgement}

The works was sponsored by the Indonesian Department of National Education under PhD research and PAR scheme. Thank to the Massey University, NZ, for her facilities during writing the manuscript.

\section{References}

Ahmad, F., \& Tan, K.H. (1986). Effect of lime and organic matter on soybean seedling growth in Aluminum-toxic soil. Soil Sci. Soc. Am. J., 50, 656 -661.

Ahmedna, M., Johns, M.M., Clarke, S.J., Marshall, W.E., \& Rao, R.M. (1977). Potential of agricultural by-product-based activated carbons for use in raw sugar decolorization. J. Sci. Food Agric., 75, 117-124.

Asai, H., Samson, B.K., Stephan, H.M., Songyikhangsuthor, K., Homma, K., Kiyono, Y., Inoue, Y., Shiraiwa, T., \& Horie, T. (2009). Biochar amendment techniques for upland rice production in Northern Laos 1. Soil physical properties, leaf SPAD and grain yield. Field Crops Research, 111, 81-84.

ASTM. (2006). Petroleum products, lubricants, and fossil fuel: Gaseous fuels, coals and cokes. ASTM, Inter, West Conshohocken, PA.

Barnhisel,, R., \& Bertsch, P.M. (1982). Aluminum. In: Page, A.L., Miller, R.H., \& Keeney, D.R. (Eds.), Methods of soil analyses, Part 2. Chemical and mineralogical properties (pp. 275-300). Madison: American Society of Agronomy and Soil Science Society of America Inc.

Blake, G..R., \& Hartge, K.H. (1986). Bulk density. In: Klute, A. (Ed), Methods of soil analysis. Part 1. Physical and mineralogical methods (pp 425-442). $2^{\text {nd }}$ Ed. Madison: American Society of Agronomy and Soil Science Society of America Inc.

Bot A., \& Benites. J. (2005). The importance of soil organic matter: Key to drought-resistant soil and sustained food production. FAO soil Bull. 2005. No. 80. Rome: FAO. 
Bremner, J.M., \& Mulvaney, C.S. (1982). Nitrogen-total. In: Page, A.L., Miller, R.H. \& Keeney, D.R. (Eds.), Methods of Soil Analyses, Part 2. Chemical and Mineralogical properties (pp. 595-624). Madison: American Society of Agronomy and Soil Science Society of America Inc.

Brown, T.T., Koenig, R.T., Hoegin, D.R., Harsh, J.B., \& Rosi, R.E. (2008). Lime effect on acidity, crop yield, and Aluminum chemistry in direct-seeded cropping system. Soil Sci. Soc. Am. J., 72, 634-640.

Chan, K.Y., van Zwieten, B.L., Meszaros, I., Downie, D., \& Joseph, S. (2007). Agronomic values of greenwaste biochars as a soil amendments. Australian Journal of Soil Research, 45, 437-444.

Chan, K.Y., Van Zwieten, B.L., Meszaros, I., Downie, D., \& Joseph, S. (2008). Using poultry litter biochars as soil amendments. Australian Journal of Soil Research, 46, 437-444.

Eagle, A.J., Bird, B.A., Horwath, W.R., Linquist, B.A., Brouder, S.M., Hill, J.E., \& Van Kessel, C. (2001). Rice yield and nitrogen utilization efficiency under alternative straw management practices. Agron. J., 92, 1096-1103.

El Sharkawi, H., Yamamoto, S., \& Honna, T. (2006). Rice yield and nutrient uptake as affected by cyanobacteria and soil amendments — a pot experiment. J. Plant Nutr. Soil Sci., 169, 809-815.

Ernsting, A., \& Smolker, R. (2009). Biochar for climate change mitigation: Fact or fiction. [Online] Available: www.biofuelwatch.org.uk/docs/biocharbriefing.pdf. February 2009. Retrieved via Internet Explorer Ver. 6, 2 October 2009.

Glaser, B., Lehmann, J., \& Zech, W. (2002). Ameliorating physical and chemical properties of highly weathered soils in the tropics with charcoal: A review. Biol Fertil Soils., 35, 219-230.

Goodman, A.M., \& Ennos, R. (1999). The effects of soil bulk density on the morphology and anchorage mechanics of the root systems of sun flower and maize. Annals of Botany, 83: 293-302.

Haby, V.A. (2002). Soil fertility and management of acid coastal plain soils for crop production. Communications in Soils Science and Plant Analysis, 33, 2497-2520.

Haefele, S.M. (2007). Black soil green rice. Rice Today, 6, 26-27.

Haefele, S.M' Knoblauch, C., Gummert, M., Konboon Y., \& Koyama, S. (2008). Black carbon (biochar) in rice-based systems: Characteristics and opportunities. In: Woods, W.I., Teixeira, W.G., Lehmann, J., Steiner, C., Prins, A.W. \& Rebellatods, L. (Eds. ). Amazon dark earths: Wim Soembrok's vision (pp 445-463. Amsterdam: Springer.

Hakim, N., Syafriman, A., \& Soepardi, G. (1989). Effect of lime, fertilizers and crop residues on yield and nutrient uptake of upland rice, soybean and maize in intercropping system. In: Heide, J.V.D. (Ed.). Nutrient management for food crop production in tropical farming system (pp 349-360). Harren, the Netherlands: Institute of Soil Fertility.

Harris, R.F., Chesters, G., \& Allen, O.N. (1966). Dynamics of soil aggregation. Advances in Agronomy. 18, $108-169$.

Hesse, P.R. (1982). The potential of soil organic matter for soil improvement. In Banta, S. \& Mendoza, C.V. (Eds). Organic matter and rice (pp 34-44). Los Banos, the Philippines: IRRI.

Kaderi, H. (2004). The technique of organic matter application on rice plant in acid sulfate soil (Indonesian). Bull. Tehnik Pertanian, 9, $34-41$.

Kaewpradit, W., Toomsan, B., Cadisch, B., Vityakon, P., Limpinuntana, V., Saenjan, P., Jogloy, S., \& Patanothai, A. (2009). Mixing groundnut residues and rice straw to improve rice yield and N use efficiency. Field Crop Research, 110, $130-138$.

Karkamar, S., Mitra, B.N., \& Gosh, B.C. (2009). Influence of industrial solid waste on soil-plant interaction in rice under acid Lateritic soils. Paper presented at World of Coal Ash (WOCA) Conference, 4 - 7 May 2009. Lexington, USA.

Lehman, J., da Silva Jr. J. P., Steiner, C., Nehls, T., Zech, W., \& Glaser, B. (2003). Nutrient availability and leaching in an archaeological Anthrosol and a Ferralsol of the Central Amazon basin: fertilizer, manure and charcoal amendments. Plant and Soil, 249, 343-357.

Liang, B., Lehmann, J., Kinyangi, D., Grossman, J., O’Neill, B., Skjemstad, J.O., Thies, J., Luizao, F.J., Peterson, J., \& Neves, E.G. (2006). Black carbon increases cation exchange capacity in soils. Soil Sci. Soc. Am. J., 70, 1719-1730.

Mahvi, A.H., Alawi, N., \& Maliki, A. (2005). Application of rice husk and its ash in Cadmium removal from aqueous solution. Pakistan Journal of Biological Sciences, 8, 721 -725.

Moore, Jr. P.A., Attanandana, A., \& Patrick, J.W.H. (1990). Factors affecting rice growth on acid sulfate Soils. Soil Sci. Soc. Am. J., 54, 1651-1656.

Novak, J.M., Busscher, W.J., Laird, D.L., Ahmedna, M., Watts, D.W., \& Niandou, M.A.S. (2009). Impact of biochar amendment on fertility of a Southeastern Coastal Plain. Soil. Soil Science, 174, 105-112. 
Ponamperuma, F.N. (1982). Straw as source nutrient for wetland rice. In S. Banta \& C.V. Mendoza (Eds.), Organic matter and rice (pp 117-136). Los Banos, the Philippines: IRRI.

Reichenauer, T.G, Panamulla, S., Subasinghe, S., \& Wimmer, B. (2009). Soil amendments and cultivar selection can improve rice yield in salt-influenced (tsunami-affected) paddy fields in Sri Lanka. Environ. Geochem. Health, 31, 573-579.

Rodríguez, L., Salazar, P., \& Preston, T. R. (2009). Effect of biochar and biodigester effluent on growth of maize in acid soils. Livestock Research for Rural Development. Volume 21, Article \#110. [Online] Available: http://www.lrrd.org/lrrd21/7/rodr21110.htm. (October 2009.)

Rondon, M. A., Lehmann, J., Ramirez, J., \& Hurtado, M. (2007). Biological nitrogen fixation by common beans (Phaseolus vulgaris L.) increases with bio-char additions. Biology and Fertility of Soils, 43, 699 -708.

Senjen, R. (2009). Biochar, another dangerous techno fix. Friend of Earth Australia. [Online] available: www.foe.au.org. Retrieved via Internet Explorer Ver. 6, 2 October 2009.

Shamshuddin, J., \& Auxtero, E.A. (1991). Soil solution composition and mineralogy of some active acid sulfate soils in Malaysia as affected laboratory incubation with lime. Soil Science, 152, $365-376$.

Shamshuddin, J, Muhrizal, S, Fauziah, I., \& Husni, M.H.A. (2004). Effects of adding organic materials to an acid sulfate soil on the growth of cocoa (Theobroma cacao L.) seedlings. Science of the Total Environment, 323, 33-45.

Shamsuddin, J., Sharifuddin, H.A.H., \& Bell, L.C. (1998). Longevity of ground magnesium limestone applied to an Ultisol. Communications in Soil Science and Plant Analysis, 29, 1299-1313.

Sharma, M.L., \& Uehara, G. (1968). Influence of soil structure in soil water relations in low humic latosols. 1. Water retention. Soil Sci. Soc. Amer. Proc., 32, 765-768.

Singh, B., Shan, Y.H, Johnson-Beebout, S.E., Singh, Y.,\& Buresh, P. (2008). Crop residue management for lowland-rice based cropping system in Asia. Advances in Agronomy, 98, 11-199.

Sitio, J., Widodo, \& Barchia, F. (2007). The use of EM 4 and rice husk ash to improve the growth and yield of rice in peat soil (in Indonesian ). Journal Akta Agrosia, 7, 36 - 40.

Soil Survey Laboratory Staff. (1992). Soil survey laboratory methods manual. Soil Survey Investigation Report No. 42, Version 2.0, USDA.

Tagoe, S.O., Takatsugu Horiuchi, T., \& Matsui, T. (2008). Effects of carbonized and dried chicken manures on the growth, yield, and N content of soybean. Plant Soil, 306, 211-220.

Thomas, B.P., Fitzpatrick, R.W., Merry, R.H., \& Hicks, W.S. (2003). Coastal acid sulfate soil management guidelines, Barker Inlet, SA. Canberra: CSIRO Land-Water.

Topoliantz, S., Ponge, J.F., \& Ballof S. (2007). Manioc peel and charcoal: a potential organic amendment for sustainable soil fertility in the tropics. Biol. Fertil. Soils, 41, 15-21.

Widjaja-Adi, I.P.G,., Nugroho, K., Ardhi. D.S., \& Karrama, S. (1992). Tidal-swamp land resources: potential, limitations and utilization. In: Partohardjono, S. \& Sam (Eds.) Development of integrated agriculture in tidal-swamp land (in Indonesian), (pp 19-38). Bogor, Indonesia: Central Soil Research Institute.

Williams, N.A., Morse, N.D., \& Buckman, J.F. (1972). Burning vs. incorporation of rice crop residues. Agron. J., 64, $467-468$.

Woolf, D. (2008). Biochar as a soil amendment: A review of the environmental implications. [Online] Available: http://orgprints.org/13268/01/Biochar_as_a_soil_amendment_-_a_review.pdf. (October 2008).

Yamato, M., Okimori,Y., Wibowo, I.F., Anshori, S., \& Ogawa, M. (2006). Effects of the application of charred bark of Acacia mangium on the yield of maize, cowpea and peanut, and soil chemical properties in South Sumatra, Indonesia. Journal Soil Science and Plant Nutrition, 52, 489-495. 
Table 1. The characteristics of rice husk biochar and 4 other soil amendments

\begin{tabular}{|l|l|l|l|l|l|}
\hline Properties & Rice straw & Rice husk & RHA & RHB & Chromolaena \\
\hline Water content $(\%)$ & 12.2 & 11.26 & 6.74 & 4.96 & 13.3 \\
\hline $\mathrm{BD}\left(\mathrm{Mg} \mathrm{m}^{-3}\right)$ & - & - & 0.96 & 0.84 & - \\
\hline $\mathrm{pH}$ & - & - & 8.4 & 8.7 & - \\
\hline $\mathrm{C}(\%)$ & 33.4 & 43.77 & 5.09 & 18.72 & 28.55 \\
\hline $\mathrm{N}(\%)$ & 0.35 & 0.32 & 0 & 0 & 0.46 \\
\hline $\mathrm{P}(\%)$ & 0.1 & 0.07 & 0.06 & 0.12 & 0.13 \\
\hline $\mathrm{CEC}\left(\mathrm{cmol} \mathrm{kg}^{-1}\right)$ & - & - & 6.7 & 17.57 & - \\
\hline $\mathrm{K}(\%)$ & 0.1 & 0.12 & 0.16 & 0.2 & 0.1 \\
\hline $\mathrm{Ca}(\%)$ & 0.12 & 0.27 & 0.33 & 0.41 & 0.18 \\
\hline $\mathrm{Mg}(\%)$ & 0.18 & 0.16 & 0.21 & 0.42 & 0.15 \\
\hline $\mathrm{Na}(\%)$ & 0.42 & 0.6 & 1.26 & 1.4 & 0.67 \\
\hline
\end{tabular}

Table 2. Effect of rice husk biochar and other soil amendments on the physical properties of acid sulfate soils of West Kalimantan, Indonesia

\begin{tabular}{|l|l|l|l|l|}
\hline $\begin{array}{l}\text { Soil } \\
\text { amendments }\end{array}$ & $\begin{array}{c}\text { BD } \\
\left(\mathrm{Mg} \mathrm{m}^{-3}\right)\end{array}$ & $\begin{array}{l}\text { Total pore } \\
(\% \mathrm{v} / \mathrm{v})\end{array}$ & $\begin{array}{l}\text { Available } \\
\text { water }(\% \mathrm{v} / \mathrm{v})\end{array}$ & $\begin{array}{l}\text { Penetration resistance } \\
\left(\mathrm{N} \mathrm{m}^{-2}\right)\end{array}$ \\
\hline Control & $1.24 \mathrm{~b}$ & $44.43 \mathrm{a}$ & $11.34 \mathrm{a}$ & $500.00 \mathrm{c}$ \\
\hline Rice straw & $1.14 \mathrm{a}$ & $52.07 \mathrm{~b}$ & $15.35 \mathrm{c}$ & $403.35 \mathrm{~b}$ \\
\hline Rice Husk & $1.16 \mathrm{a}$ & $52.10 \mathrm{~b}$ & $13.76 \mathrm{abc}$ & $410.24 \mathrm{~b}$ \\
\hline Rice Husk Ash & $1.15 \mathrm{a}$ & $54.21 \mathrm{~b}$ & $14.64 \mathrm{bc}$ & $390.00 \mathrm{a}$ \\
\hline $\begin{array}{l}\text { Rice Husk } \\
\text { Biochar }\end{array}$ & $1.17 \mathrm{a}$ & $53.16 \mathrm{~b}$ & $15.47 \mathrm{c}$ & $393.34 \mathrm{a}$ \\
\hline Cromolaena & $1.19 \mathrm{ab}$ & $47.30 \mathrm{ab}$ & $12.46 \mathrm{ab}$ & $403.30 \mathrm{~b}$ \\
\hline
\end{tabular}

Means followed by the same letters at each column are not significantly different $(\mathrm{P}=0.05)$

Table 3. Effect of rice husk biochar and other soil amendments on the chemical properties of acid sulfate soils of West Kalimantan, Indonesia

\begin{tabular}{|c|c|c|c|c|c|c|c|c|c|c|}
\hline \multirow{2}{*}{$\begin{array}{l}\text { Soil } \\
\text { amendments }\end{array}$} & \multirow{2}{*}{$\mathrm{pH}$} & \multirow{2}{*}{$\mathrm{C}(\%)$} & \multirow{2}{*}{$\begin{array}{l}\text { total } \mathrm{P} \\
(\%)\end{array}$} & CEC & $\mathrm{K}$ & $\mathrm{Ca}$ & $\mathrm{Mg}$ & $\mathrm{Na}$ & \multirow{2}{*}{$\mathrm{Al}(\%)$} & \multirow{2}{*}{$\mathrm{Fe}(\%)$} \\
\hline & & & & \multicolumn{5}{|c|}{$\left(\mathrm{cmol} \mathrm{kg}^{1}\right)$} & & \\
\hline Before exp ${ }^{1)}$ & 3.75 & 0.78 & 0.25 & 6.84 & 0.19 & 0.34 & 3.31 & 0,31 & 3.31 & 3.04 \\
\hline Control & $3.36 \mathrm{a}$ & $0.54 \mathrm{a}$ & $0,21 \mathrm{a}$ & $6.64 \mathrm{a}$ & $0.20 \mathrm{a}$ & $0.24 \mathrm{a}$ & 3.55 & 0.2 & $3.84 \mathrm{c}$ & $3.61 \mathrm{c}$ \\
\hline Rice straw & $3.68 \mathrm{ab}$ & $3.58 \mathrm{~cd}$ & $0.30 \mathrm{ab}$ & $7.32 \mathrm{bc}$ & $0.22 \mathrm{ab}$ & $0.23 \mathrm{a}$ & 3.45 & 0.24 & $3.42 \mathrm{abc}$ & $3.34 \mathrm{~b}$ \\
\hline Rice husk & $3.96 \mathrm{~b}$ & $3.73 \mathrm{~cd}$ & $0.31 \mathrm{~b}$ & $7.20 \mathrm{ab}$ & $\begin{array}{l}0.34 \\
\text { bc } \\
\end{array}$ & $0.45 \mathrm{~b}$ & 3.43 & 0.22 & $3.47 \mathrm{abc}$ & $3.22 \mathrm{ab}$ \\
\hline $\begin{array}{l}\text { Rice husk } \\
\text { ash }\end{array}$ & $3.98 \mathrm{~b}$ & $2.78 \mathrm{~b}$ & $0.27 \mathrm{ab}$ & $7.79 \mathrm{bc}$ & $\begin{array}{l}0.43 \\
\mathrm{~cd}\end{array}$ & $0.44 \mathrm{~b}$ & 3.56 & 0.25 & $3.57 \mathrm{bc}$ & $3.34 \mathrm{~b}$ \\
\hline $\begin{array}{l}\text { Rice husk } \\
\text { biochar }\end{array}$ & $4.40 \mathrm{c}$ & $4.09 \mathrm{~d}$ & $0.32 \mathrm{~b}$ & $8.03 \mathrm{c}$ & $0.51 \mathrm{~d}$ & $0.44 \mathrm{~b}$ & 3.57 & 0.32 & $2.96 \mathrm{a}$ & $3.10 \mathrm{a}$ \\
\hline Chromolaena & $4.06 \mathrm{bc}$ & $3.22 \mathrm{bc}$ & $0.29 \mathrm{ab}$ & $7.15 \mathrm{ab}$ & $0.25 \mathrm{ab}$ & $0.22 \mathrm{a}$ & $\begin{array}{l}3.45 \\
\mathrm{NS}\end{array}$ & $\begin{array}{r}0.27 \\
\text { NS }\end{array}$ & $3.31 \mathrm{ab}$ & 3.28 \\
\hline
\end{tabular}

Means followed by the same letters at each column are not significantly different $(\mathrm{P}=0.05)$

1) Soil properties before experiment 
Table 4. Effect of rice husk biochar and other soil amendments on the growth of rice growing on acid sulfate soils of West Kalimantan, Indonesia

\begin{tabular}{|l|c|l|l|c|}
\hline Soil amendment & $\begin{array}{l}\text { plant height } \\
(\mathrm{cm})\end{array}$ & $\begin{array}{l}\text { Number of } \\
\text { tillers }\end{array}$ & $\begin{array}{l}\text { Number of } \\
\text { productive tillers }\end{array}$ & $\begin{array}{l}\text { Total dry } \\
\text { biomass }(\mathrm{g})\end{array}$ \\
\hline Control & $75.17 \mathrm{a}$ & $9.00 \mathrm{a}$ & $5.00 \mathrm{a}$ & $29.53 \mathrm{a}$ \\
\hline Rice straw & $85.67 \mathrm{~b}$ & $12.00 \mathrm{~b}$ & $7.33 \mathrm{~b}$ & $50.93 \mathrm{~b}$ \\
\hline Rice husk & $84.00 \mathrm{~b}$ & $14.33 \mathrm{bc}$ & $8.00 \mathrm{~b}$ & $64.97 \mathrm{bc}$ \\
\hline Rice husk ash & $78.33 \mathrm{a}$ & $14.00 \mathrm{bc}$ & $8.00 \mathrm{~b}$ & $57.87 \mathrm{~b}$ \\
\hline Rice husk biochar & $86.17 \mathrm{~b}$ & $17.33 \mathrm{~d}$ & $9.67 \mathrm{c}$ & $75.93 \mathrm{c}$ \\
\hline Chromalaena & $85.00 \mathrm{~b}$ & $15.00 \mathrm{~cd}$ & $10.00 \mathrm{c}$ & $76.50 \mathrm{c}$ \\
\hline
\end{tabular}

Means followed by the same letters at each column are not significantly different $(\mathrm{P}=0.05)$

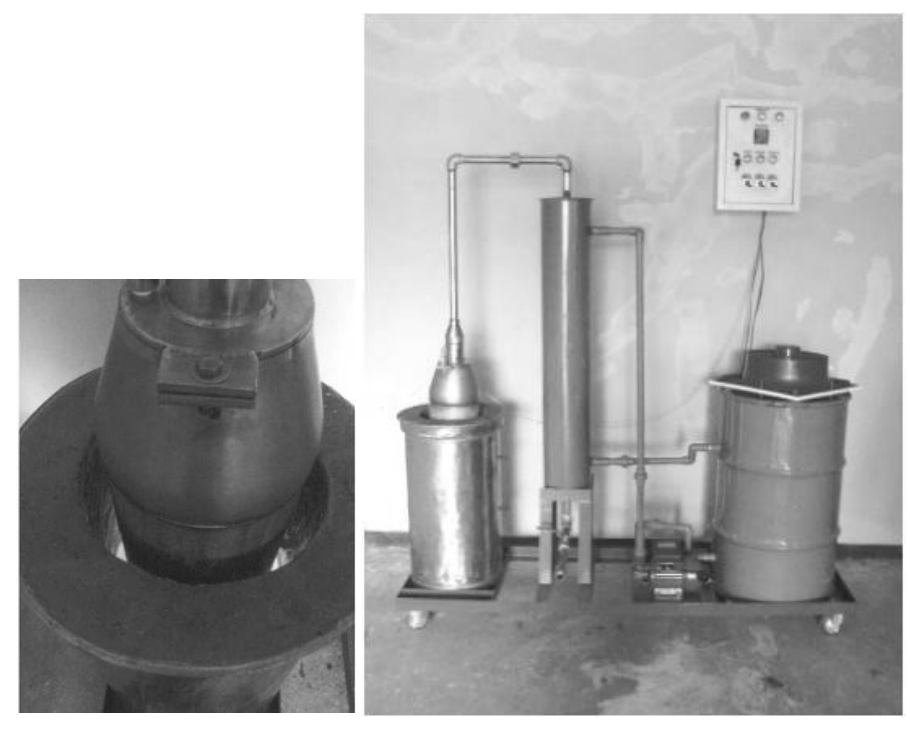

Figure 1. The reactor pyrolysis for producing rice husk biochar 